\title{
CUSTOMER EXPECTATIONS \& HIERARCHY OF NEEDS IN GUI IN THE CASE OF ONLINE SERVICES MARKETING
}

\author{
1 Prof. Chithambar Gupta V \\ ${ }^{2}$ Prof. Chandrasekhar Rao V
}

\section{The Importance of Service Sector}

In the global economy of the early twenty-first century the division of labour between Asia's giants is clear. China, with its manufacturing prowess has earned the title of "Factory of the world". Whereas, India is likely to retain its tag as the "Back office of the world" for the time being, but the country is expected to face competition from its neighbour, China and other developing countries, in the long run. India has high hopes for its burgeoning trade in business-support services and many other professional services. Global off shoring has a market volume of roughly $\$ 70$ billion, with India's share in the global market totaling 45 per cent. No doubt, skill and labour intensive services sector is India's strength and will remain its strength. But as a matter of fact, Indian service firms are under enormous pressure to reinvent their labour arbitrage-driven outsourcing model which has come under severe strain from a variety of forces - growing commoditization of services, rising protectionism, pricing pressure, competition from newer locations and also new technologies. Indian service firms have to move up the value chain by re-positioning and re-branding of its high quality services. This enables the sector to scale up faster, to beat the rising competition, using the vast and dynamic domestic market and the availability of low-cost, highly skilled workers, as a stepping stone.

\section{The Importance of e-Services}

In today's e-world, it is imperative that more and more services go the web way. With India witnessing an exponential growth in the usage of computers and also the penetration of internet, it is only natural that many service providers are choosing the e-way. Online shopping is the process whereby consumers directly buy goods or services from a seller in real-time, without an intermediary service, over the Internet. If an intermediary service is present the process is called electronic commerce. An online shop, e-shop, e-store, internet shop, web shop, web store, online store, or virtual store evokes the

up ofphysical analogy of buying products or services at a briéks-and-mortar retailer or in a shopping mall. An onliphe service provider, can for example, be an internet service provider, email provider, news ALPRóvider (press), entertainment provider (music, movies), search, e-shopping site (online stores), efinance or e-banking site, e-health site, egovernment site. As we see the mushrooming of online services in almost all the sectors of services, the challenge before the marketers of services is to provide some sort of tangibility to online services. Online services being highly intangible and high on experience and credence qualities, packaging the online services become a herculean task. It is a wellknown fact that 'Packaging acts as a silent salesman' in the case of marketing of products. In the case of online services, the 'Graphical User Interface' (or popularly known as GUI) of the website, through which the service is provided, acts as the only packaging element.

\footnotetext{
${ }_{1}$ Prof. Chithambar Gupta V

Mob : 9740641820

2 Prof. Chandrasekhar Rao V

Mob : 9986959441

E-mail : vcgupta01@gmail.com

E-mail : velchasekhar@gmail.com
}

Dept of Management Studies - Reva Institute of Technology \& Management (RITM)

Kattigenahalli, Jala Hobli, Yelahanka, Bangalore - 560064 Ph: 6568 7563 / 64/ 65 www.revainstitution.org 
GUI :

A Graphical User Interface (GUI), often pronounced gooey, is a type of user interface that allows users to interact with programs in more ways than typing such as computers; hand-held devices such as MP3 players, portable media players or gaming devices; household appliances and office equipment with images rather than text commands. A GUI offers graphical icons, and visual indicators, as opposed to text-based interfaces, typed command labels or text navigation to fully represent the information and actions available to a user. The actions are usually performed through direct manipulation of the graphical elements. The term GUI is historically restricted to the scope of twodimensional display screens with display resolutions capable of describing generic information.

\section{Importance of good User Interface Design :}

A good user interface design can spell the difference between acceptance of a software product and its failure in the marketplace. If the end"users find the software to be too cumbersome or difficult to understand, then an otherwise excellent product could be doomed to failure. The service provider's goal should be to make the software as professional"looking and easy to use as possible.

Sadly, a great many companies "especially small or highly specialized service firms " pay little attention to the mechanics of good user interface style. "As long as it works, that's what matters!" seems to be their mantra, with little regard to the inconvenience that this imposes on the user.

An online service firm should invest considerable effort into making out user interfaces as intuitive and foolproof as possible. Similarly, the software should allow the user to perform tasks quickly and efficiently, without sacrificing power and flexibility.

Sometimes, the shortcomings can often be cured using a few simple guidelines. For example, it helps if the user can enter data using buttons and list boxes, instead of typing it in by hand. It helps if the software provides pop"up dialog boxes, to guide the user along the way. Even the Judicious choice of icons and other graphics can turn a steep learning curve into a short and gentle slope.
Graphical user interface design in website projects typically have input forms and interactive modules for users to input information and data into. Making these user-friendly and intuitive is imperative to allow the visitor to conclude a certain activity on the site. User interface navigation must be intuitive, and forms must have minimal confusing choices. User interface design is good mix of design elements, data input elements, easy to understand text and the effective grouping of these elements. It also takes into account the importance of keyword placement and optimized content. Graphic User interfaces (GUI) were designed to give users proper control over their computers. Most websites, whether a business or a plain one, focus more on the GUI of their sites as users expect a level of sophistication from web pages also. The main objective is to create an interface that does not place unnecessary obstacles in the path thereby assuring easy navigability. Another important aspect of a good graphic user interface is an efficient hierarchy of information. Users need to have information in Dinin possible steps. Well-optimized content page s on the site will bring in relevant traffic and GALVISitors. An effective user interface design will ensure that these visitors understand the

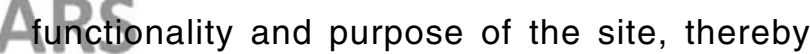
increasing the sustenance of the site. Consistency of design \& structure in the user interface design process across the site will ensure the growth of visitors' comfort level in navigating through the site. Non user-friendly interfaces will turn users away who may not return for a second try.

\section{Challenges for GUI in Indian Scenario}

Effectively used, GUI of the website will act as a silent salesman in the online scenario. Online service encounters being predominantly remote encounters, it is important for the service providers to have a robust GUI as per the customers' expectations. The problem multiplies manifold in the case of countries like India, where-in predominantly all the websites are written in English, whereas all the target audience are not English-literate. We have, in India, a variety of audience like computer 
illiterates, people with limited computer literacy, people who are proficient in using computers, English-illiterates, people who know English as a first language / second language / third language and people who are proficient in English. In India, we also have the problems with band-width - like very slow dial-up connections, slow / medium / high speed broad band connections. A good GUI should be able to factor in all the above scenarios and also should be fast enough, useful, visually appealing, easy-touse and easy-to-understand.

\section{Literature Review}

Much fascination and speculation surrounds the impact of the World Wide Web on consumer shopping behavior. In the emerging electronic environment, knowing how to create customer centered Web sites is of great importance. Sirrka L. Jarvenpaa \& Peter A. Todd (1996) gathered consumers' reactions via an open-ended survey using a sample of 220 shoppers. The study found that the shopping experience was reported to be generally enjoyable, but at the same time frustrating. Nearly everyone in the sample had something negative to say about customer service on the World Wide Web, judging that the sites were not designed to be responsive to their needs and that the presentation of goods and services seemed intangible. Overall, the results suge gest that Web sites need to think more about how they perform on the factors known to affect consumer behavior; namely, product perceptions, shopping experience, and customer service.

Ping Zhang and Gisela M. von Dran (2002) reports two studies on user perceptions of Web sites. The results showed that (1) customers' quality expectations change over time, and thus no single quality checklist will be good for very long, (2) customers in a Web domain do not regard all quality factors as equally important, and (3) the rankings of important quality factors differ from one Web domain to another, but certain factors were regarded as highly important across all the domains studied.

Alex M. Susskind (2004) conducted a telephone survey of 204 residents and participants' perceptions of the World Wide Web usage were investigated.
The study found distinct differences between general communication-related and commerce-related apprehensiveness. The findings indicated that general WWW apprehensiveness and the misuse of personal information were strongly related to participants' WWW purchasing apprehensiveness for commercial transactions.

The study conducted by, Marwan Mohamed Abdeldayem (2010), draws on 242 questionnaire surveys of university students in Dubai, UAE. The analysis of these surveys reveals that attitudes toward online shopping and the intention to shop online are not only affected by ease of use, usefulness, and enjoyment, but also by some other factors such as perceived Web-store traits, channel traits and consumer traits.

\section{Need for the study}

Unfortunately, a lot of websites are designed based on the likes and dislikes of the business owners up of themselves, without due consideration of how the Awe ó site will be perceived and used by the end user, Ta target audience. Identifying the target audience, and ouilding a website user interface design process around this user's abilities and perception is very $\triangle$ important for the success of any website. To address this need the authors have conducted this study to Ofindout the perceptions of the users of the online services and to find the factors important for a good GUI from a user perspective.

\section{Objectives of the study}

When the customers go to an online shop, a couple of factors determine whether they will return to the site. The most important factors are the ease of use and the presence of user-friendly features. Next to that, there is a difference in experience: experienced users focus more on the variables that directly influence the task, while novice users are focusing more on understanding the information. The objectives of the study:

To identify the characteristics of an effective GUI

$>$ To identify the factors which the online users value the most 
To identify the satisfaction levels of the online users with the factors

$>$ To determine what percentage of the overall satisfaction can be explained with the help of the key critical factors.

$>$ To determine and suggest the focus areas for the service providers

\section{Research Methodology \& Data Collection}

A set of ten attributes have been identified, which are regarded as important for a good GUI. The ten factors are as listed below :

1. Visual Appeal

2. Ease of use for first-time users

3. Speed of loading at various time intervals

4. Ease of Navigation between the pages

5. Availability of Help \& guidance facilities

6. Easy to understand for non-English speakers

7. Easy to operate for people with low-computer skills

8. Option of vernacular language (support)

9. Proper error messages at various input points

10. Availability of query, enquiry, chat, messaging, SMS facilities \& other useful links to other websites.

A survey was conducted on the online service users, with a sample size of 100 . Convenience sampling was used to collect the data. A questionnaire was administered to all the respondents.

The respondents are asked to rate the online service website that they use, on these set of ten attributes on a Likert scale of 1 to 5 ( 5 being Excellent and 1 being Poor).

The respondents were also asked to give an overall rating of the website on the same Likert scale of 1 to 5 ( 5 being Excellent and 1 being Poor).

\section{Data Validation \& Analysis}

Based on the survey results, and statistical analysis (with SPSS) of the results, an attempt is made to identify the important factors, which influences the customer satisfaction, and the ranking of all the other attributes from the customers' perspective.

The 'Overall rating of the website' is taken as the dependent variable and the ten attributes in the questionnaire are taken as the independent variables that will affect the dependent variable. The 'Statistical Package for Social Sciences (SPSS)' was used to analyze the data. Appropriate statistical analyses were performed to test the hypothesis of this study. The study and analysis of the data collected of the influence of the chosen variables on over all rating of the site, reveals that every variable has some positive impact on the overall rating of the site, as predicted and chosen by the researchers for the study.

ANOVA test is used to know whether all the regression coefficients are valid for study by making a hypothesis,

$\mathrm{H}_{\mathrm{o}}=$ All regression coefficients are zero and will not impact the over all rating.

The test results are presented in Table 1.

\section{Table 1}

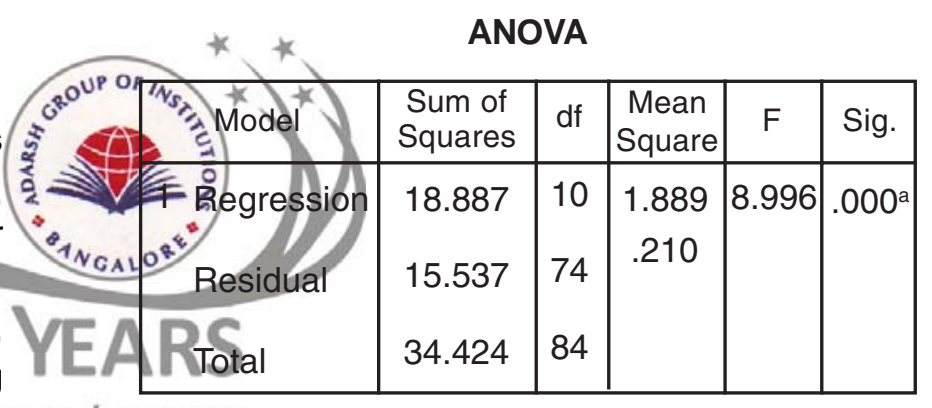

771 to a.Predictors: (Constant), availability of query, easy to understand, ease of navigation, visual appeal, proper error message, ease of use, easy to operate, speed of loading, availability of help, option of vernacular.

\section{b. Dependent Variable: overall rating}

If the $F$ probability or significance value in the ANOVA table is less then 0.05 , we reject the null hypothesis (at $0.95 \%$ confidence level) that the category of variables taken into study has no impact on the over all rating of the site. From the output table for the ANOVA, we see that the significant value of $F$ is 0.000 ; therefore we reject the null hypothesis and conclude that the variables under study have significant impact on over all rating.

Regression Analysis \& T-test were performed on the data to find out the significance of each factor and the extent and direction of significance of each factor on the dependent variable. 
For this a regression equation was fitted with all the ten independent variables with the dependent variable. The results of the test are presented in Table 2.

Table - 2 : Regression coefficients of chosen variables related to 'over all rating of GUI Coefficients $^{\mathrm{a}}$

\begin{tabular}{|c|c|c|c|c|c|c|c|c|}
\hline & \multirow{2}{*}{ Model } & \multicolumn{2}{|c|}{$\begin{array}{c}\text { Unstandardized } \\
\text { Coefficients }\end{array}$} & \multirow{2}{*}{$\begin{array}{c}\begin{array}{c}\text { Standardized } \\
\text { Coefficients }\end{array} \\
\text { Beta }\end{array}$} & \multirow[b]{2}{*}{$\mathbf{t}$} & \multirow[b]{2}{*}{ Sig. } & \multicolumn{2}{|c|}{$\begin{array}{l}95.0 \% \text { Confidence } \\
\text { Interval for B }\end{array}$} \\
\hline & & B & $\begin{array}{l}\text { Std. } \\
\text { Error }\end{array}$ & & & & $\begin{array}{l}\text { Lower } \\
\text { Bound }\end{array}$ & $\begin{array}{l}\text { Upper } \\
\text { Bound }\end{array}$ \\
\hline \multirow[t]{11}{*}{1} & (Constant) & .818 & .365 & & 2.240 & .028 & .090 & 1.545 \\
\hline & Visual Appeal & .134 & .081 & .153 & 1.654 & .102 & -.027 & .295 \\
\hline & Ease of Use & .228 & .066 & .322 & 3.457 & .001 & .097 & .359 \\
\hline & Speed of Loading & .036 & .059 & .059 & .615 & .541 & -.082 & .154 \\
\hline & Ease of Navigation & .198 & .073 & .245 & 2.697 & .009 & .052 & .344 \\
\hline & Availability of Help & .068 & .057 & .117 & 1.193 & .237 & -.046 & .182 \\
\hline & Easy to Understand & -.136 & .066 & -.201 & -2.050 & .044 & -.268 & -.004 \\
\hline & Easy to Operate & .147 & .071 & .196 & 2.059 & .043 & .005 & .289 \\
\hline & Option of Vernacular & -.002 & .055 & -.004 & -.041 & .968 & -.111 & .107 \\
\hline & Proper Error Message & .070 & .064 & & & .279 & -.058 & .198 \\
\hline & Availabilty of Query & .030 & .065 & & & .640 & -.099 & .159 \\
\hline
\end{tabular}

Table 3: Model Summary

\begin{tabular}{|c|c|c|c|c|}
\hline Model & $\mathrm{R}$ & $\mathrm{R}$ Square & $\begin{array}{c}\text { Ajusted } \\
\mathrm{R} \text { Square }\end{array}$ & $\begin{array}{c}\text { Std. Error of the } \\
\text { Estimate }\end{array}$ \\
\hline 1 & $.741^{\mathrm{a}}$ & .549 & .488 & $\begin{array}{c}\text {.45821 } \\
\text { to }\end{array}$ \\
\hline
\end{tabular}

a. Dependent Variable: overall rating

Thus the regression equation model is as follows: Over all rating $=.818$ (Constant) +0.134 (Visual appeal) +0.228 (Ease of use) +0.036 (Speed of loading $)+0.198$ (Ease of navigation) +0.068 (Availability of help) - 0.136 (Easy to understand) + 0.147 (Easy to operate) - 0.002 (Option of vernacular) +0.070 (Proper error message) +0.030 (Availability of query).

This model explains almost all the variables shows there is a change in overall rating when a change happens in variables. From the ' $t$ ' test values in the Table 2, it is inferred that the ease of use, ease of navigation, easy to understand, easy to operate have significant effect on overall rating of site as sig. ('t' probability) $<0.05$, and other 6 factors are having negligible significance on the rating as their sig. ('t' probability) $>0.05$. More over, independent variables chosen have high over all correlation $R=$ 0.741 , which is evident, from Table 3 and $\mathrm{R} 2=0.488$, shows regression equation is fit and can be considered.

Factor Analysis test was conducted on the data to identify the four most significant variables that have the maximum impact on the dependent variable. Factor analysis technique is used to determine the variables, which are to be considered through quartimax rotation. 
Table 4

Total Variance Explained

\begin{tabular}{|c|c|c|c|c|c|c|c|c|c|}
\hline \multirow{2}{*}{$\begin{array}{c}\text { Compo } \\
\text { nent }\end{array}$} & \multicolumn{3}{|c|}{ Initial Eigenvalues } & \multicolumn{3}{|c|}{$\begin{array}{c}\text { Extraction Sums of Squared } \\
\text { Loadings }\end{array}$} & \multicolumn{3}{|c|}{$\begin{array}{c}\text { Extraction Sums of Squared } \\
\text { Loadings }\end{array}$} \\
\hline & Total & $\begin{array}{c}\% \text { of } \\
\text { Variance }\end{array}$ & $\begin{array}{c}\text { Cumulative } \\
\%\end{array}$ & Total & $\begin{array}{c}\% \text { of } \\
\text { Variance }\end{array}$ & $\begin{array}{c}\text { Cumulative } \\
\%\end{array}$ & Total & $\begin{array}{c}\% \text { of } \\
\text { Variance }\end{array}$ & $\begin{array}{c}\text { Cumulative } \\
\%\end{array}$ \\
\hline 1 & 3.940 & 35.819 & 35.819 & 3.940 & 35.819 & 35.819 & 2.783 & 25.299 & 25.299 \\
\hline 2 & 1.368 & 12.439 & 48.258 & 1.368 & 12.439 & 48.258 & 1.741 & 15.826 & 41.124 \\
\hline 3 & 1.085 & 9.863 & 58.121 & 1.085 & 9.863 & 58.121 & 1.582 & 14.378 & 55.502 \\
\hline 4 & 1.038 & 9.436 & 67.557 & 1.038 & 9.436 & 67.557 & 1.326 & 12.055 & 67.557 \\
\hline 5 & .837 & 7.613 & 75.170 & & & & & & \\
\hline 6 & .673 & 6.118 & 81.288 & & & & & & \\
\hline 7 & .501 & 4.553 & 85.842 & & & & & & \\
\hline 8 & .488 & 4.433 & 90.275 & & & & & & \\
\hline 9 & .472 & 4.287 & 94.562 & & & & & & \\
\hline 10 & .331 & 3.009 & 97.571 & & & & & & \\
\hline 11 & .267 & 2.429 & 100.000 & & & & & & \\
\hline
\end{tabular}

Extraction Method: Principal Component Analysis.

Through looking at the factors extracted and their eigen values and the cumulative percentage of variance, we see that in cumulative percent column that the 4 factors extracted together account for each of the ten independent variables to assess the nearly $68 \%$ of the total variance of information $\mathrm{F}$ individual rating of each factor based on the contained in the ten original variables, while we lost customer perception. The results are presented in around $32 \%$ for the remaining factors. Which 71 tothefollowing Table 5.

Table-5

Statistics

\begin{tabular}{|c|c|c|c|c|c|c|c|c|c|c|}
\hline & $\begin{array}{l}\text { visual- } \\
\text { appeal }\end{array}$ & $\begin{array}{l}\text { ease__ } \\
\text { of_use }\end{array}$ & $\begin{array}{l}\text { speed__ } \\
\text { of } \\
\text { loading }\end{array}$ & $\begin{array}{c}\text { ease }_{-} \\
\text {of } \\
\text { naviga- } \\
\text { tion } \\
\end{array}$ & $\begin{array}{c}\text { availabil- } \\
\text { ity__ } \\
\text { of_help } \\
\end{array}$ & $\begin{array}{c}\text { easy_to_ } \\
\text { under- } \\
\text { stand }\end{array}$ & $\begin{array}{c}\text { easy }_{-} \\
\text {to_- } \\
\text { operate }\end{array}$ & $\begin{array}{c}\text { option_- } \\
\text { of_- } \\
\text { vernacu- } \\
\text { lar } \\
\end{array}$ & $\begin{array}{c}\begin{array}{c}\text { proper__ } \\
\text { error_- } \\
\text { message }\end{array} \\
\end{array}$ & $\begin{array}{l}\text { availabilty } \\
\text { of_query }\end{array}$ \\
\hline N Valid & 100 & 100 & 100 & 100 & 100 & 100 & 100 & 100 & 100 & 100 \\
\hline Missing & 0 & 0 & 0 & 0 & 0 & 0 & 0 & 0 & 0 & 0 \\
\hline Mean & 3.8800 & 3.7100 & 3.3000 & 3.7300 & 3.5100 & 2.7300 & 2.9900 & 2.1300 & 3.4800 & 3.3900 \\
\hline Std. Deviation & .75585 & .92436 & 1.02000 & .80221 & 1.09632 & .94125 & .88186 & 1.14287 & .95853 & 1.12721 \\
\hline
\end{tabular}

Among the rating given for the factors the following factors are given priority by the customers based on the mean values which are more than 3.5
1. Visual appeal
2. Ease of use
3. Ease of navigation
4. Availability of help 
Where in visual appeal is the one which turned out to be as the highest motivating factor to the customers to transact on the web site.
Correlation Test was conducted to find out the correlation between each individual variable to the overall rating. The results of the correlation test are presented in Table 6.

Table-6

\begin{tabular}{|c|c|c|c|c|c|c|c|c|c|c|}
\hline & $\begin{array}{l}\text { visual- } \\
\text { appeal }\end{array}$ & $\begin{array}{l}\text { ease_- } \\
\text { of_use }\end{array}$ & $\begin{array}{l}\text { speed_ } \\
\text { of___ } \\
\text { loading }\end{array}$ & $\begin{array}{c}\text { ease_- } \\
\text { of_- } \\
\text { naviga- } \\
\text { tion }\end{array}$ & $\begin{array}{l}\text { availabil- } \\
\text { ity_ } \\
\text { of_help }\end{array}$ & $\begin{array}{c}\text { easy_to } \\
\text { under- } \\
\text { stand }\end{array}$ & $\begin{array}{c}\text { easy_ } \\
\text { to__ } \\
\text { operate }\end{array}$ & $\begin{array}{l}\text { option_- } \\
\text { of_- } \\
\text { vernacu- } \\
\text { lar }\end{array}$ & $\begin{array}{c}\text { proper_- } \\
\text { error_- } \\
\text { message }\end{array}$ & $\begin{array}{l}\text { availabilty } \\
\text { of_query }\end{array}$ \\
\hline \multirow[t]{2}{*}{ overall_rating } & $.341^{* *}$ & $.514^{* *}$ & $.370^{* *}$ & $.438^{* *}$ & $.451^{* *}$ & .109 & $.353^{* *}$ & .069 & $.415^{* *}$ & $.417^{\star *}$ \\
\hline & .001 & .000 & .000 & .000 & .000 & .281 & .000 & .493 & .000 & .000 \\
\hline
\end{tabular}

Surprisingly if the correlation values are considered (vide table-6), we can conclude that the maximum correlation is with 'easy to use' factor and this is the major influencer out of the four significant variables that are influencing the overall rating of the site.

\section{Limitations of the Study}

The study has the following limitations:

o The sample size is restricted to 100

o The data is collected in the city of Bangalore only.

\section{Findings \& Suggestions}

The survey conducted on the online users and the further analysis of the data collected throws in some important findings, as presented below :

$>$ The four factors - 'Ease of use for firsttime users', 'Ease of navigation between the pages', 'Easy to understand for nonEnglish speakers' and 'Easy to operate for people with low computer skills' have significant effect on overall rating of site.

$>$ These four factors put together contribute close to $68 \%$ of the overall satisfaction of the site.

$>$ Based on the individual ratings of the ten variables, users have rated high on the following four variables - 'Visual appeal', 'Ease of use for first-time users', 'Ease of navigation between the pages' and 'Availability of help'.
It can hence be inferred that 'Ease of use for first-time users' and 'Ease of navigation between the pages' are very important for the overall satisfaction and the users are quite happy on these parameters.

It can also be derived that factors like, 'Easy to understand for non-English speakers' and 'Easy to operate for people with low computer skills' are very important for the overall satisfaction, but they have not been rated high by the current users. The online service providers need to concentrate on these factors which are very important from the customer's perspective but are not happy with the current setup.

\section{1 toReferênces}

1. Sirrka L. Jarvenpaa , Peter A. Todd, Consumer reactions to electronic shopping on the world wide web, International Journal of Electronic Commerce, v. 1 n.2, p.59-88, December 1996

2. Marwan Mohamed Abdeldayem, (2010), A study of customer satisfaction with online shopping: evidence from the UAE, International journal of Advanced Media and Communication.

3. P. Zhang, G. von Dran, Expectations and Rankings of Website Quality Features: Results of Two Studies on User Perceptions, Proceedings of the 34th Annual Hawaii International Conference on System Sciences ( HICSS-34)-Volume 7, p.7019, January 03-06, 2001 
4. Peterson, R. A., Balasubramanian, S., \& Bronnenberg, B. J. (1997). Exploring the implications of the Internet for consumer marketing. Journal of the Academy of Marketing Science, 25, 329-346.

5. Huang, M. (2000) Information load: its relationship to online exploratory and shopping behavior. International Journal of Information Management 20: 337-347.

6. Falk, Louis K.; Sockel, Hy; Chen, Kuanchin. (2005) 'E-Commerce and Consumer's Expectations: What Makes a Website Work." Journal of Website Promotion, 1(1)

(65-75)
7. Steve Elliot and Sue Fowell, "Expectations versus reality: a snapshot of consumer experiences with Internet retailing", International Journal of Information Management 20 (2000): 323-336

8. Ram L. Kumar et al., "User interface features influencing overall ease of use and personalization", Information \& Management 41 (2004): 289-302

9. Sherry Y. Chen en Robert D. Macredie, "The assessment of usability of electronic shopping: A heuristic evaluation", International Journal of Information Management 25 (2005), 516-532
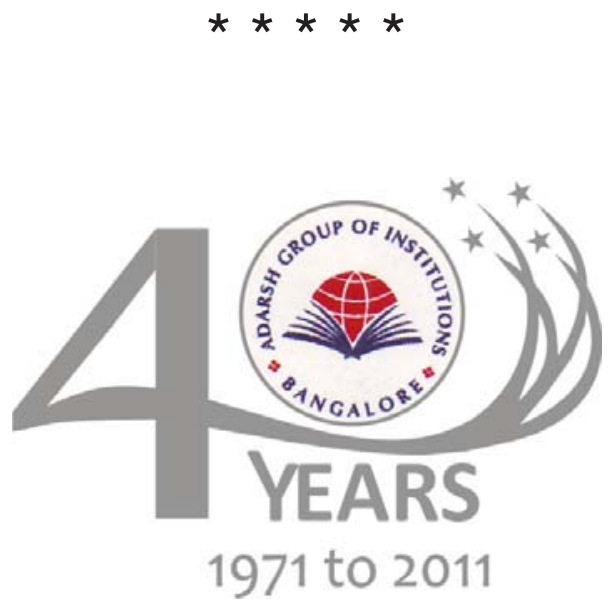